\title{
Comentario de libro
}

\author{
ANDREA FABIANA MERAHED \\ MARISOL GARCIA
}

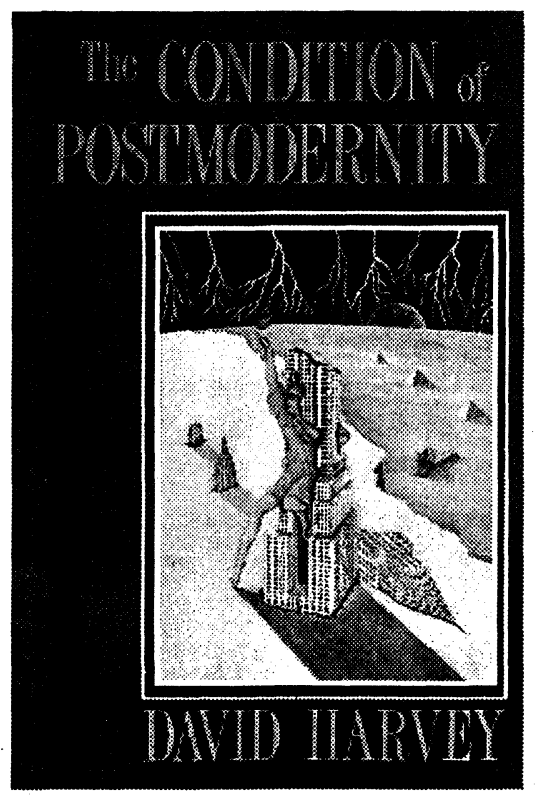

HARVEY, David. The Condition of Postmodernity. An Enquiry into the Origins of Cultural Change. Massachusetts. USA. Blackwell Inc. 1991.

En nuestros días se da a menudo la utilización del término Posmodernismo, sin estar claro aún cuales son sus orígenes, sus objetivos, y sus fundamentos. Es por ello que especialistas de distintos campos se abocan al estudio de este término con el fin de encontrar respuestas ante tanta incertidumbre. Entre tantas publicaciones sobre el tema una de los mas destaca- das por su amplitud analítica es el texto de David Harvey «La condición Posmoderna. Una encuesta alrededor del origen del cambio cultural» (1990), texto aún no traducido al idioma español.

Ante los primeros contactos de David Harvey con el término posmodernismo su reacción hacia él -señala- ha sido la misma que tuvo hacia varios «ismos» que se han ido sucediendo en el par de décadas pasadas. Dado que en la realidad, el clamor de los argumentos posmodernistas, aumentó sustancialmente, consideró apropiado adentrarse más profundamente en la naturaleza del posmodernismo, no como un «arsenal de nuevas ideas» sino como una condición histórica que requería aclaración.

El resultado es el texto que analizamos.

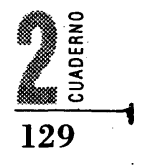

Este consta de cuatro partes, dedicando la primera al estudio de las ideas dominantes ya que el posmodernismo le resultó un campo minado de nociones conflictivas. El resto del trabajo examina el contexto políticoeconómico antes de haber minado mucho más atentamente a la expe- 
riencia del espacio y tiempo como una importante línea de mediación entre el dinamismo del desarrollo histórico geográfico del capitalismo y complejos procesos de producción cultural y transformación ideológica.

David Harvey parte del análisis del término modernismo, ya que toma como único punto de partida considerado para entender el posmodernismo, la posible relación entre ambos. Algunos ven al posmodernismo como una legítima reacción hacia la «monotonía» de la visión universal del mundo del modernismo.

Generalmente percibidos como positivistas tecnocéntricos y racionalistas, el modernismo universal ha sido identificado con la creencia de un proceso lineal, el planeamiento racional de estratos sociales ideales y la estandarización del conocimiento y la producción. El posmodernismo, en contraste, pone en privilegio «heterogeneidad y diferencia como fuerzas liberadoras en la redefinición del discurso cultural».

Fragmentación, indeterminación o discursos totalizadores marcan la diferencia entre ambos pensamientos.

En lo relativo a la temática que nos compete, David Harvey plantea al posmodernismo como la ruptura con las ideas modernistas con respecto al planeamiento y desarrollo en planes urbanos, dejado así lo racional, eficiente y la arquitectura sin adorno (funcionalistas - superficies del estilo internacional).

El Posmodernismo responde de una forma fragmentada con un «co- llage» de usos corrientes, todo esto apelando a un eclecticismo de estilos arquitectónicos. Es así como el autor señala las diferencias de concepción del espacio para el modernismo y el posmodernismo: los primeros ven al espacio como algo a ser moldeado para propósitos sociales y subordinados a la construcción de un proyecto social, mientras que para los posmodernistas el espacio es algo independiente y autónomo, a ser moldeado de acuerdo con objetivos estéticos y principios totalmente independientes de ningún objetivo social, salvo tal vez, el logro de una belleza «desinteresada» y sin tiempo como objetivo en sí mismo. El posmodernismo responde a la autodiversificación y a la necesidad de expresar estéticamente los diversos problemas, pero esto lleva a la comunicación a través de la arquitectura diferenciando grupos de clientes en una forma más individualizada, lógicamente este individualismo privilegia a un grupo económicamente alto y medio, que el posmodernismo busca satisfacer desvergonzadamente en el mercado, todo esto no es más que buscar respuestas como signos de status satisfaciendo los gustos, de ahí en más, según Harvey el posmodernismo es antivanguardista.

Si ha habido algún tipo de transformación en la economía política del capitalismo de finales de siglo, entonces corresponde establecer cuan profundo y fundamental puede ser el cambio. Para esto David Harvey se remite a aceptar la visión de que el «boom» de la larga posguerra, desde 
1945 a 1973, fue construida sobre ciertas políticas de control laboral, combinaciones tecnológicas, hábitos de consumo y configuraciones de poder político y económico, y que esta configuración puede ser razonablemente llamada Fordismo-Keynesianismo. El quiebre de este sistema a partir de 1973 ha inaugurado un período de rápidos cambios y de incertidumbres.

Existe siempre un peligro de confusión con respecto a lo transitorio y lo efímero con transformaciones fundamentales en la vida político-económica. Pero el contraste entre las prácticas políico-económicas presente y aquellas del período de posguerra, es suficientemente fuerte como para hacer la hipótesis de un cambio desde el fordismo a lo que podría llamarse «régimen de acumulación flexible». En este sentido el autor hace referencia a que un régimen de acumulación

"describe la estabilización sobre un largo periodo del reparto del producto neto entre consumo $y$ acumulación, esto implica alguna correspondencia entre la transformación de las condiciones de producción y de las condiciones de reproducción».

Existen dos extensas áreas de dificultad con el sistema económico capitalista: la primera surge de las cualidades anárquicas del mercado de fijación de precios y la segunda deriva de la necesidad de tener un control suficiente sobre la manera en que el poder laboral es desplegado para garantizar la suma de valor en la producción y beneficios positivos para tantos capitalistas como sea posible. Para los trabajadores el hecho de habituarse al modo capitalista fue un largo proceso histórico (y particularmente no muy feliz); es así que tuvo que ser renovado con la suma de cada nueva generación dentro de la fuerza laboral. Disciplinar el poder laboral con el objetivo de la acumulación del capital es algo muy intrincado ya que requiere «control».

David Harvey se vale de la interpretación del espacio-tiempo como para relacionar cultura, política y economía para poder llegar a una mejor comprensión de la totalidad.

Al mirar hacia atrás, se observa que los variados movimientos que llevaron al modernismo a su apogeo, tuvieron que desarrollar una nueva lógica en la concepción del espacio. La organización del espacio se ha transformado en el problema estético primario de la cultura de mediados de siglo, como el problema del tiempo fue el problema estético y primario en las primeras décadas de este siglo. Se atribuye el cambio posmoderno a una crisis en la experiencia de espacio y tiempo, una crisis en la cual las categorías espaciales dominan a las de tiempo. Espacio y tiempo son categorías básicas de la existencia humana.

En estas dos últimas décadas se ha experimentado una intensa fase de compresión espacio-temporal que ha 
tenido un impacto desorientador $y$ destructivo sobre las prácticas en todas las áreas. La transición a la acumulación flexible fue en parte llevada a cabo a través del rápido despliegue de nuevas formas de organización y nuevas tecnologías de producción. La propiedad de la televisión masiva unida a la comunicación satelital, hace posible experimentar un bombardeo de imágenes desde diferentes espacios casi simultáneamente, colapsando los espacios del mundo en una serie de imágenes en la pantalla de televisión. La imagen de espacios y lugares se hace tan abierta a la producción y al uso efímero como cualquier otra.

$\mathrm{Al}$ disminuir las barreras espaciales se vuelve mucho más sensitivo a lo que contienen los espacios mundiales.

El mercado ha sido siempre un «emporio de estilos», pero ahora luce muy diferente de lo que era hace veinte años. Espacios de muy diversos mundos parecen colapsar unos con otros, así como las mercancías mundiales son montadas en los supermercados y todas las formas de subculturas se yuxtaponen en la ciudad contemporánea. La compresión espacio-temporal siempre apunta a la capacidad de asirse a las realidades que se despliegan en la vida cotidiana, sus condiciones exageran en muchos aspectos los dilemas que han acosado de tiempo en tiempo a los mecanismos capitalistas de modernización en el pasado.

La intensidad de la compresión espacio temporal en el capitalismo occidental desde los ' 60 con todas sus congruentes figuras de lo excesivamente efímero y fragmentado en lo político y privado, así como en el reino de lo social sí parecen indicar un contexto que hace a la posmodernidad, en cierto modo especial

En síntesis, el autor en el texto analiza los distintos aspectos que pueden llegar a tener relación con el término «posmoderno» y su condición, brindando al lector un vasto bagaje de posibilidades de llegar a sus propias conclusiones. Es probablemente por este motivo que David Harvey no incluye una conclusión general en su libro, incitando al lector a continuar la búsqueda de información acerca del posmodernismo. 